\title{
A mountain of millipedes III: A new genus for three new species from the Udzungwa Mountains and surroundings, Tanzania, as well as several 'orphaned' species previously assigned to Odontopyge Brandt, 1841 (Diplopoda, Spirostreptida, Odontopygidae)
}

\author{
Henrik ENGHOFF \\ Natural History Museum of Denmark, University of Copenhagen, Universitetsparken 15, DK-2100 \\ København Ø, Denmark, email: henghoff@snm.ku.dk \\ urn:1sid:zoobank.org:author:FB09A817-000D-43C3-BCC4-2BC1E5373635
}

\begin{abstract}
The new genus Geotypodon gen. nov. is described. It includes two species from the Udzungwa Mountains: G. millemanus gen. et sp. nov. (type species) and G. submontanus gen. et sp. nov., one species from nearby Iringa: G. iringensis gen. et sp. nov., and 18 previously described species hitherto incorrectly assigned to Odontopyge Brandt, 1841.
\end{abstract}

Keywords. Eastern Arc, taxonomy, new species.

Enghoff H. 2016. A mountain of millipedes III: A new genus for three new species from the Udzungwa Mountains and surroundings, Tanzania, as well as several 'orphaned' species previously assigned to Odontopyge Brandt, 1841 (Diplopoda, Spirostreptida, Odontopygidae). European Journal of Taxonomy 177: 1-19. http://dx.doi.org/10.5852/ ejt.2016.177

\section{Introduction}

This is the third in a series of articles about the millipedes, especially the endemic Afrotropical family Odontopygidae, of the Udzungwa Mountains, Tanzania. For general information on the Odontopygidae and the Udzungwa Mountains see the first article in the series (Enghoff 2014); see also Enghoff \& Frederiksen (2015).

In the present article three further new odontopygid species are described from the Udzungwa Mountains and their immediate surroundings (Fig. 1). The new species resemble several species which were assigned to the genus Odontopyge Brandt, 1841 by Kraus (1960) and authors before him. However, Hoffman (1991) showed that Odontopyge had been misinterpreted by virtually everybody dealing with the genus after its original description and that Odontopyge is the correct name for a genus until then known as Omopyge Manfredi, 1941. Hoffman (1991) rectified the situation and formally synonymized Omopyge under Odontopyge, but by this action he left a large number of species originally described in or subsequently transferred to Odontopyge 'orphaned', i.e., without a valid genus name. Some of these have been transferred to other genera by Hoffman \& Howell $(1981,2012)$, Hoffman $(2000,2002)$ and Frederiksen \& Enghoff (2015), but very many remain orphaned. 
Kraus (1960) was aware of the situation and therefore accepted Attems'(1909) designation of Odontopyge kilimandjaronus Attems, 1909, as type species of Odontopyge, mentioning that the ICZN would be asked to make Attems' designation valid. This, however, has not happened, and Attems' type designation remains invalid, as does that of Silvestri (1896: Julus bicuspidatus Brandt, 1841) (Jeekel 1970).

Table 1 lists all species assigned to Odontopyge by Kraus (1960) and subsequent authors, with an indication of their subsequent re-classification. Part 2 of the table includes the dubious species of 'Odontopyge' listed by Kraus (1960) - many of these names were based on female specimens and may never be resolvable.

To accommodate the new species described here, a new genus is established to which several of the orphaned species can be assigned as well.

\section{Material and methods}

The material for this article comes from the zoological collections of the Natural History Museum of Denmark, University of Copenhagen (ZMUC). The specimens were partly collected during field trips

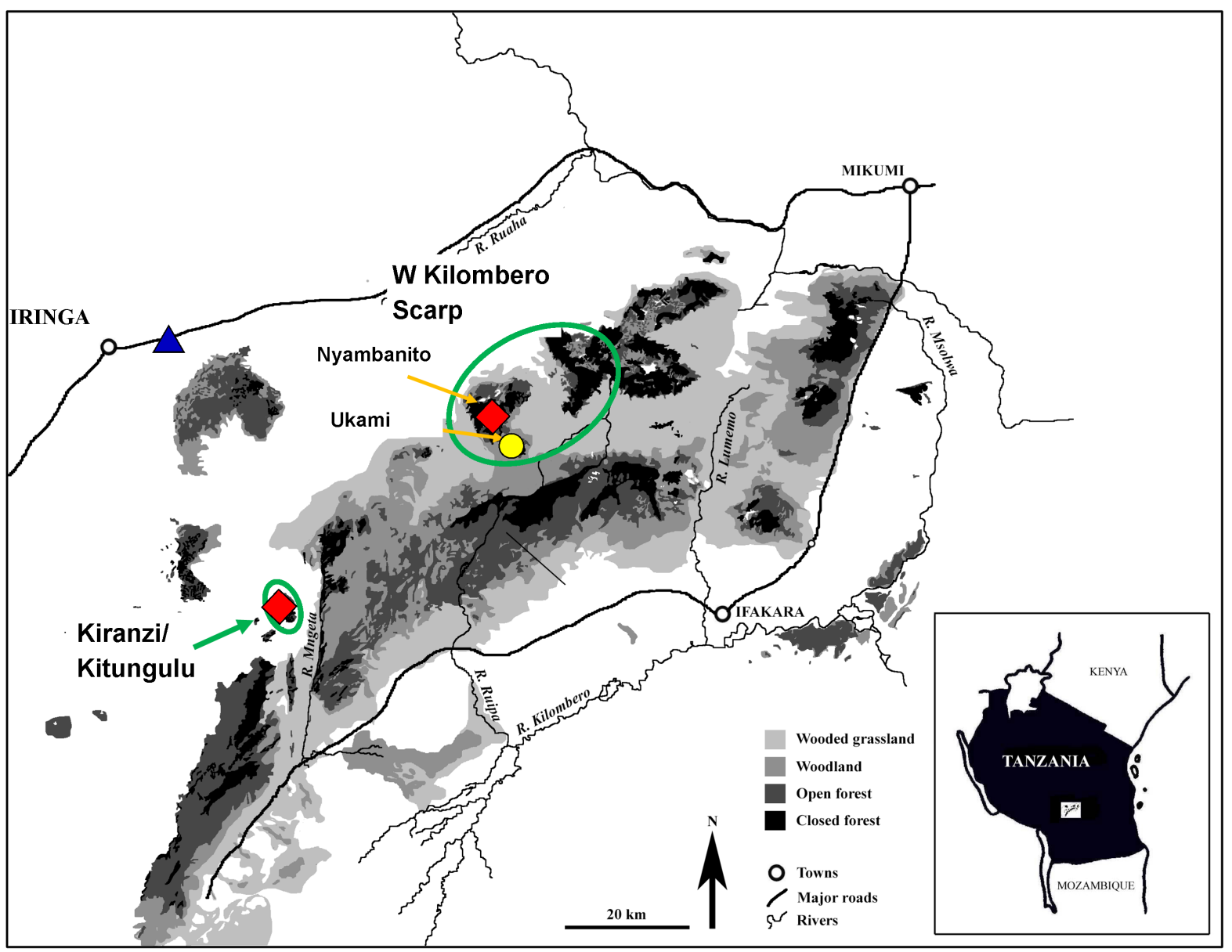

Fig. 1. Map of the Udzungwa Mountains, showing the collecting sites for the three new Geotypodon species, as well as names of the Forest Reserves in question and names of individual mountains in West Kilombero FR. Red diamonds = G. millemanus gen. et sp. nov., yellow dot: G. submontanus gen. et sp. nov., blue triangle: G. iringensis gen. et sp. nov. Based on fig. 1 in Marshall et al. (2010) and information in Doody et al. (2001). 
ENGHOFF H., New millipede genus and species from the Udzungwa Mts

Table 1. Species of Odontopyge sensu auctorum nec Brandt, 1841. The table is based on Kraus (1960), with updates as indicated. Part 1 of the list contains species placed by Kraus and subsequent authors in Odontopyge. Part 2 contains the "nomina dubia" listed by Kraus (1960). Numerous additional species originally described in Odontopyge and transferred to other genera by Kraus and his predecessors are not listed.

Part 1. Species assigned to 'Odontopyge sensu auctorum' by Kraus and subsequent authors.

\begin{tabular}{|c|c|c|c|}
\hline & Species & Current placement & Reference \\
\hline Odontopyge & angolana Kraus, 1958 & Geotypodon comb. nov. & \\
\hline Odontopyge & antrophila Attems, 1951 & 'orphaned' & \\
\hline Odontopyge & arrogans (Attems, 1935) & 'orphaned' & \\
\hline Odontopyge & astragalus (Attems, 1912) & 'orphaned' & \\
\hline Odontopyge & bayoni Silvestri, 1910 & Geotypodon comb. nov. & \\
\hline Odontopyge & carli Kraus, 1960 & Geotypodon comb. nov. & \\
\hline Odontopyge & citernii Silvestri, 1910 & 'orphaned' & \\
\hline Odontopyge & delitescens Attems, 1935 & 'orphaned' & \\
\hline Odontopyge & dewittei Kraus, 1958 & 'orphaned' & \\
\hline Odontopyge & difficilis Silvestri, 1895 & 'orphaned' & \\
\hline Odontopyge & dispersa Carl, 1909 & Geotypodon comb. nov. & \\
\hline Odontopyge & dorsalis Carl, 1909 & Calyptomastix & Hoffman (2012) \\
\hline Odontopyge & errata Kraus, 1960 & Geotypodon comb. nov. & \\
\hline Odontopyge & francosudanica Attems, 1914 & 'orphaned' & \\
\hline Odontopyge & gracilitarsus Kraus, 1958 & Geotypodon comb. nov. & \\
\hline Odontopyge & heteromodesta Kraus, 1960 & Geotypodon comb. nov. & \\
\hline Odontopyge & indecisus Pierrard, 1970 & Geotypodon comb. nov. & Pierrard (1970) \\
\hline Odontopyge & intermedia Carl, 1909 & Geotypodon comb. nov. & \\
\hline Odontopyge & kakandae Kraus, 1958 & Calyptomastix & Hoffman (2012) \\
\hline Odontopyge & kandti kandti Carl, 1909 & 'orphaned' & \\
\hline Odontopyge & kandti denticulata Attems, 1937 & 'orphaned' & \\
\hline Odontopyge & kilembeensis Demange, 1990 & 'orphaned' & Demange (1990) \\
\hline Odontopyge & kilimanjarona Attems, 1909 & Rhamphidarpoides & Frederiksen \& Enghoff (2015) \\
\hline Odontopyge & latifolia (Attems, 1914) & Callistodontopyge & Hoffman \& Howell (1981) \\
\hline Odontopyge & leviceps (Attems, 1909) & Calyptomastix & Hoffman (2012) \\
\hline Odontopyge & medjensis (Chamberlin, 1927) & 'orphaned' & \\
\hline Odontopyge & meneliki Attems, 1927 & 'orphaned' & \\
\hline Odontopyge & multianulata Attems, 1914 & Geotypodon comb. nov. & \\
\hline Odontopyge & ollieri Silvestri, 1907 & Geotypodon comb. nov. & \\
\hline Odontopyge & paludosa (Attems, 1953) & 'orphaned' & \\
\hline Odontopyge & pardalis (Gerstäcker, 1873) & Calyptomastix & Hoffman (2012) \\
\hline Odontopyge & picea Attems, 1938 & Geotypodon comb. nov. & \\
\hline Odontopyge & procera Attems, 1914 & Geotypodon comb. nov. & \\
\hline Odontopyge & procerula Kraus, 1960 & Geotypodon comb. nov. & \\
\hline Odontopyge & punctulata Attems, 1912 & Geotypodon comb. nov. & \\
\hline Odontopyge & scaphula Attems, 1912 & 'orphaned' & \\
\hline Odontopyge & sennae Brölemann, 1903 & Geotypodon comb. nov. & \\
\hline Odontopyge & severini Silvestri, 1897 & 'orphaned' & \\
\hline Odontopyge & simplex (Chamberlin, 1927) & 'orphaned' & \\
\hline
\end{tabular}




\begin{tabular}{lll} 
Odontopyge & specularis Attems, 1927 & Geotypodon comb. nov. \\
Odontopyge & stenotarsa Attems, 1938 & Geotypodon comb. nov. \\
Odontopyge & terebrum Ribaut, 1907 & 'orphaned' \\
Odontopyge & tumidens Karsch, 1881 & 'orphaned' \\
Odontopyge & uvirensis Kraus, 1960 & 'orphaned' \\
Odontopyge (?) vanutellii Silvestri, 1898 & 'orphaned' \\
\hline
\end{tabular}

Part 2. Nomina dubia listed by Kraus (1960).

\begin{tabular}{|c|c|c|c|}
\hline $\begin{array}{l}\text { Original genus } \\
\text { (subgenus) }\end{array}$ & Species & Current placement & Reference \\
\hline $\begin{array}{l}\text { Spirostreptus } \\
\text { (Odontopyge) }\end{array}$ & acutus Karsch, 1881 & & \\
\hline $\begin{array}{l}\text { Spirostreptus } \\
\text { (Odontopyge) }\end{array}$ & aequalis Porath, 1982 & & \\
\hline Odontopyge & amaura Brolemann, 1926 & & \\
\hline Odontopyge & angolensis Karsch, 1881 & & \\
\hline Odontopyge & anomala Silvestri, 1896 & & \\
\hline Odontopyge & attenuata Silvestri, 1895 & & \\
\hline Odontopyge & bicolor Silvestri, 1897 & & \\
\hline Iulus (Spirostreptus) & bicuspidatus Brandt, 1841 & & \\
\hline Spirostreptus & binodifer Voges, 1878 & & \\
\hline Ctenoiulus & chatelainei Cook, 1893 & Ctenoiulus & Hoffman (1980) \\
\hline Odontopyge & dilatata Brölemann, 1905 & & \\
\hline Odontopyge & dimidiatiformis Porat, 1893 & & \\
\hline Odontopyge & diversicolor Silvestri, 1895 & & \\
\hline Odontopyge & diversifacies Silvestri, 1898 & & \\
\hline Odontopyge & doriae Silvestri, 1896 & & \\
\hline Odontopyge & ecarinata Porat, 1894 & & \\
\hline Odontopyge & exquisita Silvestri, 1896 & & \\
\hline Iulus (Spirostreptus) & flavotaeniatus Brandt, 1841 & & \\
\hline $\begin{array}{l}\text { Spirostreptus } \\
\text { (Odontopyge) }\end{array}$ & foveolatus Porath, 1872 & & \\
\hline $\begin{array}{l}\text { Spirostreptus } \\
\text { (Odontopyge) }\end{array}$ & furcatus Karsch, 1881 & $\begin{array}{l}=\text { Ctenoiulus chatelainei } \\
\text { Cook, } 1893\end{array}$ & Hoffman (1980) \\
\hline Odontopyge & gestrii Silvestri, 1896 & & \\
\hline Iulus (Spirostreptus) & gracilicornis Brandt, 1841 & & \\
\hline Odontopyge & jallae Silvestri, 1896 & & \\
\hline Iulus (Spirostreptus) & kollarii Brandt, 1841 & Odontopyge & Hoffman (1991) \\
\hline Odontopyge & litoranea Silvestri, 1897 & & \\
\hline
\end{tabular}


ENGHOFF H., New millipede genus and species from the Udzungwa Mts

\begin{tabular}{|c|c|c|c|}
\hline $\begin{array}{l}\text { Spirostreptus } \\
\text { (Odontopyge) }\end{array}$ & maculatus Karsch, 1881 & Callistodontopyge & $\begin{array}{l}\text { Hoffman \& Howell } \\
\text { (1981) }\end{array}$ \\
\hline $\begin{array}{l}\text { Spirostreptus } \\
\text { (Odontopyge) }\end{array}$ & mitellatus Karsch, 1881 & Callistodontopyge & Hoffman (2002) \\
\hline $\begin{array}{l}\text { Spirostreptus } \\
\text { (Odontopyge) }\end{array}$ & praetextus Porath, 1872 & & \\
\hline Odontopyge & puerilla Daday, 1889 & & \\
\hline $\begin{array}{l}\text { Spirostreptus } \\
\text { (Odontopyge) }\end{array}$ & puncticaudis Porath, 1872 & & \\
\hline Odontopyge & rubripes Silvestri, 1895 & & \\
\hline Odontopyge & ruspolii Silvestri, 1896 & & \\
\hline Spirostreptus & scaliger Gerstäcker, 1873 & & \\
\hline Odontopyge & $\begin{array}{l}\text { trivialis var. strigulosa Porat, } \\
1891\end{array}$ & & \\
\hline Odontopyge & subelegans Silvestri, 1897 & & \\
\hline Spirostreptus & sugillatus Gerstäcker, 1873 & Callistodontopyge & $\begin{array}{l}\text { Hoffman \& Howell } \\
\text { (1981) }\end{array}$ \\
\hline Odontopyge & trivialis Porat, 1894 & & \\
\hline Odontopyge & uebicola Silvestri, 1896 & & \\
\hline
\end{tabular}

by ZMUC staff and students, partly by the NGO Frontier Tanzania (see Marshall et al. 2001). A total of seven male specimens was examined. All are kept in $70 \%$ alcohol.

Specimens were examined in alcohol under a stereo microscope. Specimens for scanning electron microscopy (SEM) were transferred to $96 \%$ ethanol, then to acetone, air-dried, mounted on aluminium stubs or on pieces of flexible aluminium tape and in turn mounted on stubs, coated with platinumpalladium and studied in a JEOL JSM-6335F scanning electron microscope.

See Enghoff (2014) for the description standards used.

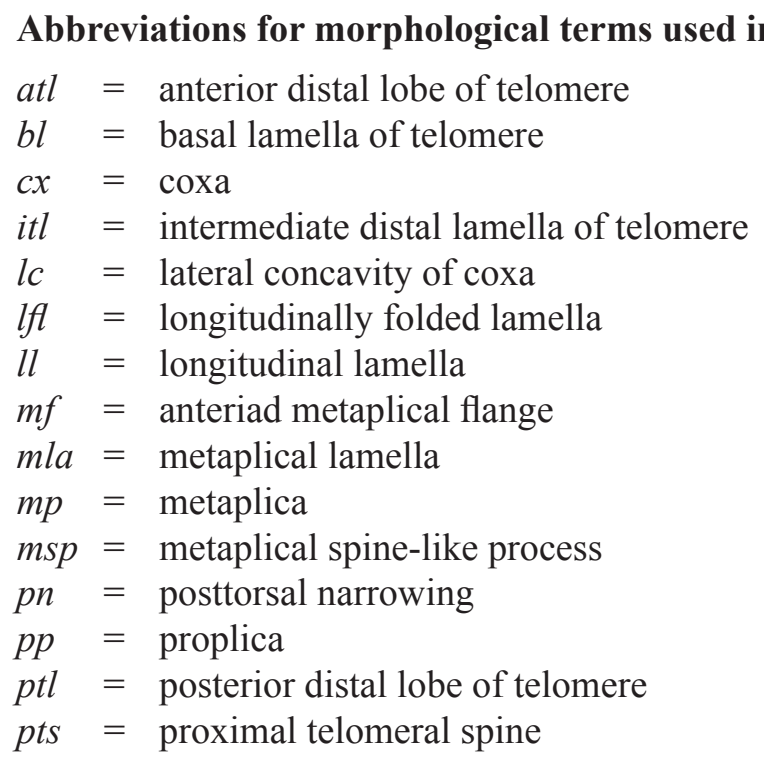




$$
\begin{aligned}
s l m & =\text { solenomere } \\
t l & =\text { terminal lobe of telomere } \\
t t & =\text { torsotope }
\end{aligned}
$$

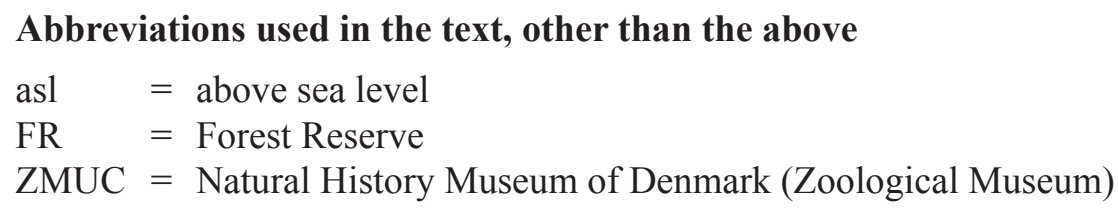

\section{Results}

\section{Taxonomy}

Class Diplopoda Blainville-Gervais, 1844

Order Spirostreptida Brandt, 1833

Family Odontopygidae Attems, 1909

Subfamily Archepyginae Manfredi, 1939

Tribe Prionopetalini Hoffman, 1991

Geotypodon gen. nov.

urn:lsid:zoobank.org:act:54706BDE-AF06-42BC-A2B3-F2D23A097B28

\section{Type species}

G. millemanus gen. et sp. nov.

\section{Diagnosis}

A genus of Odontopygidae-Prionopetalini characterized by: a long basad metaplical spine on the anterior side of the coxa, a compact torsotope, lack of pretorsal or torsal spines/processes, a pronounced posttorsal narrowing without spines, a division of the telopodite into solenomere and telomere immediately distal to posttorsal narrowing, a spine emerging from the base of the telomere and curving more or less parallel to the basal parts of the solenomere, a slender, whip-like, smooth solenomere without any outgrowths or appendages (except sometimes a tiny subapical spine), a highly three-dimensional telomere consisting of various lobes and lamellae with largely smooth margins.

\section{Etymology}

An anagram of Odontopyge. To be regarded as masculine in analogy with other names ending in -odon.

\section{Other species included:}

G. angolanus (Kraus, 1958) (comb. nov. ex Odontopyge)

G. bayoni (Silvestri, 1910) (comb. nov. ex Odontopyge)

G. carli (Kraus, 1960) (comb. nov. ex Odontopyge)

G. dispersus (Carl, 1909) (comb. nov. ex Odontopyge)

G. erratus (Kraus, 1960) (comb. nov. ex Odontopyge)

G. gracilitarsus (Kraus, 1958) (comb. nov. ex Odontopyge)

G. heteromodestus (Kraus, 1960) (comb. nov. ex Odontopyge)

G. indecisus (Pierrard, 1970) (comb. nov. ex Odontopyge)

G. intermedius (Carl, 1909) (comb. nov. ex Odontopyge)

G. iringensis gen. et sp. nov.

G. multianulatus (Attems, 1914) (comb. nov. ex Odontopyge)

G. ollieri (Silvestri, 1907) (comb. nov. ex Odontopyge) 
G. piceus (Attems, 1938) (comb. nov. ex Odontopyge)

G. procerus (Attems, 1914) (comb. nov. ex Odontopyge)

G. procerulus (Kraus, 1960) (comb. nov. ex Odontopyge)

G. punctulatus (Attems, 1912) (comb. nov. ex Odontopyge)

G. sennae (Brölemann, 1903) (comb. nov. ex Odontopyge)

G. specularis (Attems, 1927) (comb. nov. ex Odontopyge)

G. stenotarsus (Attems, 1938) (comb. nov. ex Odontopyge)

G. submontanus gen. et sp. nov.

\section{Descriptive notes}

Species of Geotypodon gen. nov. have a typical odontopygid habitus (Fig. 2) and are mostly mediumsized by odontopygid standards (cf. Kraus 1966). Published numbers of podous rings range from 49 (G. ollieri) to 72 ( $G$. multianulatus) (one has been subtracted from the published numbers because these include the telson), and published male body diameters range from $1.7 \mathrm{~mm}$ (G. sennae) to $5.5 \mathrm{~mm}$ (G. specularis). The majority of species have 54-66 podous rings and a diameter of $4.3-5.5 \mathrm{~mm}$, but there is a group of smaller species ( $G$. angolanus, G. erratus, G. heteromodestus, G. ollieri) with 49-54 podous rings and a diameter of $2.2-3.2 \mathrm{~mm}$. G. sennae is a particularly slender species: $66-68$ podous rings and $1.7 \mathrm{~mm}$ diameter, and G. multianulatus, true to its name (at least as misspelled by Kraus (1960): multiannulatus), stands out with 72 podous rings and $4.8 \mathrm{~mm}$ diameter. Of the new species described here, G. millemanus gen. et sp. nov. falls neatly in the main group, G. submontanus gen. et sp. nov. is slightly more slender than the main group, whereas $G$. iringensis gen. et sp. nov. has a larger body diameter than any other described congener (Fig. 3).

Several of the species assigned to Geotypodon gen. nov. have the same type of limbus (with handlike lobes) as the type species; this is true of G. angolanus, G. carli, G. erratus, G. gracilitarsus, G. procerulus and G. punctulatus (Attems 1912; Kraus 1958, 1960) as well as G. submontanus gen. et sp. nov. Other species have other types of limbus: G. heteromodestus, G. indecisus, G. multianulatus, $G$. piceus, G. sennae, G. specularis and G. stenotarsus (Attems 1914, 1927, 1938, 1953 [G. heteromodestus, as Haplothysanus modestus]; Brölemann 1903; Pierrard, 1970), as well as G. iringensis gen. et sp. nov. The limbus of procerus somewhat but not quite resembles that of G. millemanus gen. et sp. nov. (Attems 1914), and no information is available about this character in G. bayoni, G. dispersus or G. intermedius. On the other hand, several species outside Geotypodon gen. nov. as here defined have the same type of limbus as G. millemanus gen. et sp. nov.. This is, for example, the case for several species of Rhamphidarpoides Kraus, 1960, including R. kilimandjarona (Attems, 1909), R. ruandensis Kraus, 1960, and R. regina (Carl, 1909) (Attems 1914; Kraus 1960; Frederiksen \& Enghoff 2015), Helicochetus spp. (e.g., Kraus 1966: figs 83-87), Solenozophyllum kazibaense Kraus, 1958 and 'Odontopyge' dewittei Kraus, 1958.

\section{Remarks}

Although Geotypodon gen. nov. is proposed to accommodate several species of Odontopyge sensu Kraus (1960), its diagnosis and circumscription are narrower. Species of Odontopyge sensu Kraus (1960), may thus lack a long basad metaplical spine on the anterior side of the coxa (present in Geoptypodon), may have spines in the torsal region (absent in Geotypodon gen. nov.), and may lack a spine emerging from the base of the telomere and curving more or less parallel to the basal parts of the solenomere (present in Geotypodon gen. nov.).

None of the characters listed in the diagnosis are exclusive to Geotypodon gen. nov.: Notably, the conspicuous coxal metaplical anterior spine is also found in, e.g., several species of Rhamphidarpoides and Raduliverpa Frederiksen \& Enghoff, 2015 (Frederiksen \& Enghoff 2015) as well as Spinotarsus Attems, 1909 (Kraus 1960, 1966), but the species in question differ from Geotypodon gen. nov. by 
either having the solenomere with spines or fluting (Rhamphidarpoides, Raduliverpa) or by having characteristic structures on the telomere ("Basallamelle" and/or "Bogenlamelle" sensu Kraus 1960) (Spinotarsus).

A spine emerging from the base of the telomere is also found in several other 'Odontopyge' species, e.g., citernii Silvestri, 1898, difficilis Silvestri, 1895, and severini, Silvestri, 1897 - see Kraus (1960), where this spine is called "Tibialdorn". It is also found in Rhamphidarpoides species (Frederiksen \& Enghoff 2015), in Calyptomastix kakandae (Kraus, 1958), as well as several Spinotarsus species, etc. In the Chaleponcus dabagaensis-group there is a spine at almost the same place, but emerging from the base of the solenomere instead of the base of the telomere (Enghoff 2014).

Considering the notorious mosaic-like distribution of morphological characters throughout the family, the genus Geotypodon gen. nov. as defined here is quite possibly not a monophyletic group, cf. the Discussion section (see below). Until a more satisfactory analysis of relationships within Odontopygidae becomes available, the new genus can, however, serve as a 'home' for several (but not all) 'orphaned' species hitherto classified in Odontopyge.

Geotypodon millemanus gen. et sp. nov. urn:1sid:zoobank.org:act:D65889F9-1063-4FBB-AEBB-A594052220B1

Figs 1-4

\section{Diagnosis}

A species of Geotypodon gen. nov. in which the gonopod coxal metaplica is produced mesad in a thin lamella, a small longitudinal lamella, perpendicular to the other, is present on the anterior part of the

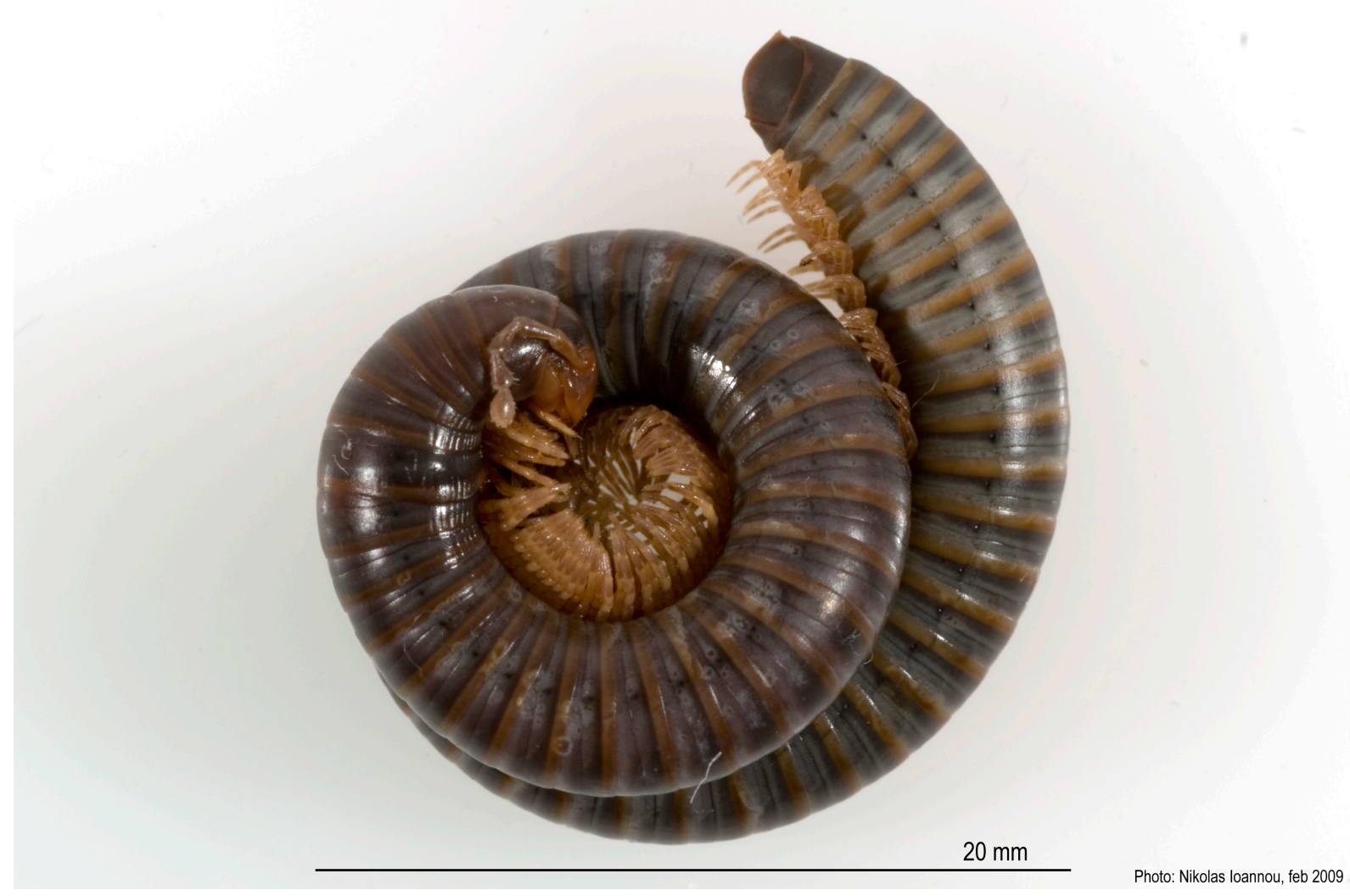

Fig. 2. Geotypodon millemanus gen. et sp. nov., paratype from West Kilombero Scarp FR after nine years in alcohol. Photograph by N. Ioannou. 
metaplica, the telomere is apically divided into two lobes of approximately equal size, and the limbus lobes are multi-cusped, hand-like. It shares these characters with G. submontanus gen. et sp. nov., but differs from that species in larger size, straight mesal margin of metaplical lamella and absence of a spine-like process on the posterior apical telomeral lobe.

\section{Etymology}

The name is a Latin noun in apposition, meaning "a thousand hands" and referring to the hand-like limbus lobes. A specimen with a diameter of $5 \mathrm{~mm}$ will have a body perimeter of approximately $15 \mathrm{~mm}$. Assuming that the limbus covers only $10 \mathrm{~mm}$, and taking into account that each "hand" occupies about 10 microns of the perimeter, each body ring will carry about a thousand "hands", and a specimen with 60 body rings will therefore have roughly 60,000 "hands".

Material studied (total: $4 \hat{\jmath}$ )

Holotype

TANZANIA: ${ }^{\lambda}$, Iringa Region, Iringa District, Udzungwa Mts, West Kilombero Scarp FR, 07050'38.4"S, $36^{\circ} 22^{\prime} 17.6^{\prime \prime}$ E, montane forest, 1390-1410 m asl, Plot Paradiso, casual, 18 Nov. 2000, Frontier Tanzania leg. (ZMUC00040350).

\section{Paratypes}

TANZANIA: $2 \hat{\delta} \hat{\partial}$, same data as holotype (ZMUC100969, ZMUC00040345); $1 \hat{\jmath}$, Iringa Region,

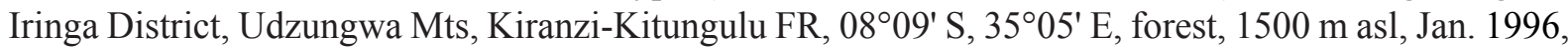
M. Andersen, P. Gravlund \& A. Jakobsen leg. (ZMUC00046991).

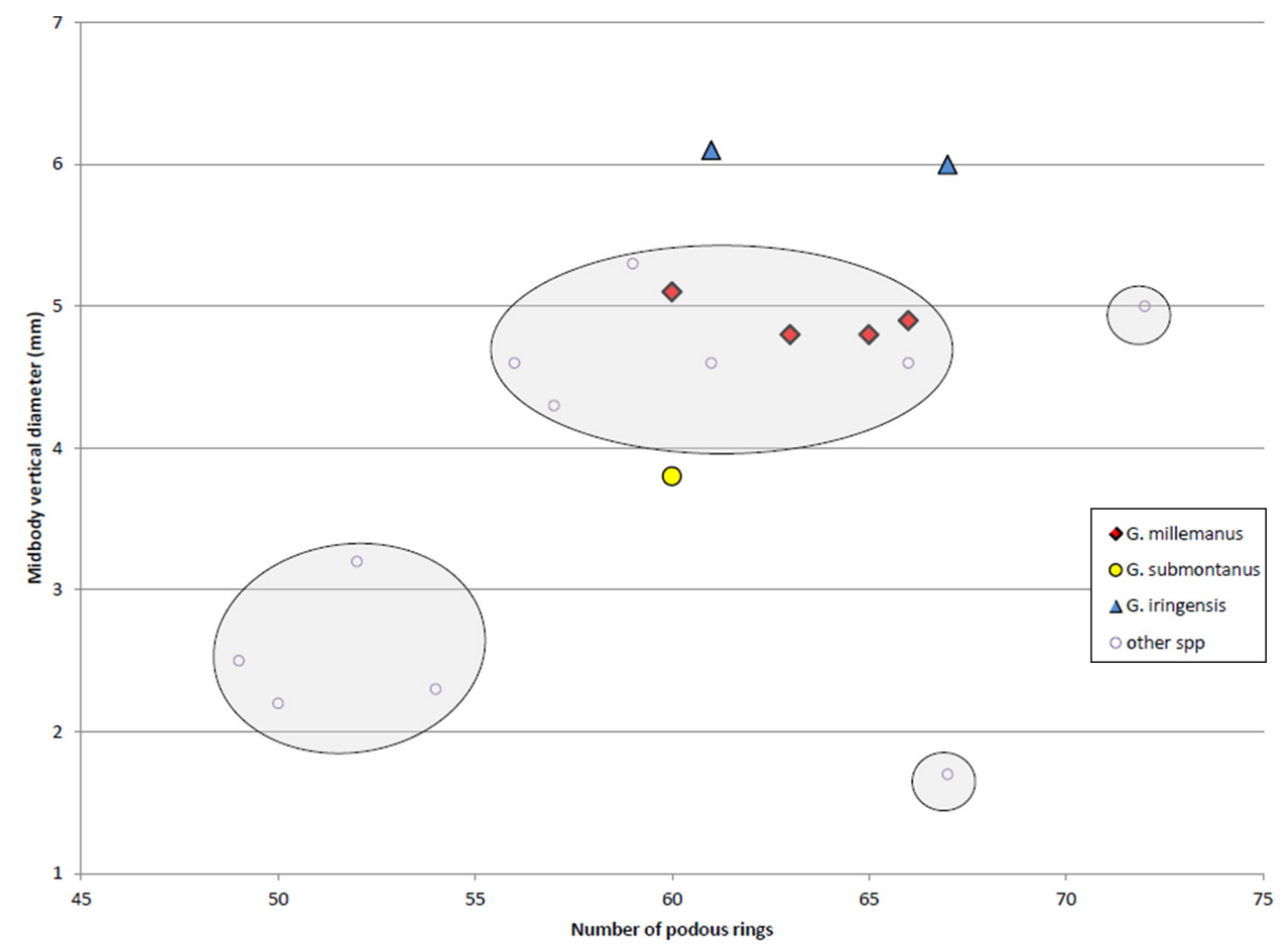

Fig. 3. Body size of males of Geotypodon spp. Bold symbols indicate numbers of podous rings and midbody vertical diameter of the new species described here. Small circles and shaded areas indicate published measurements for other Geotypodon species. 

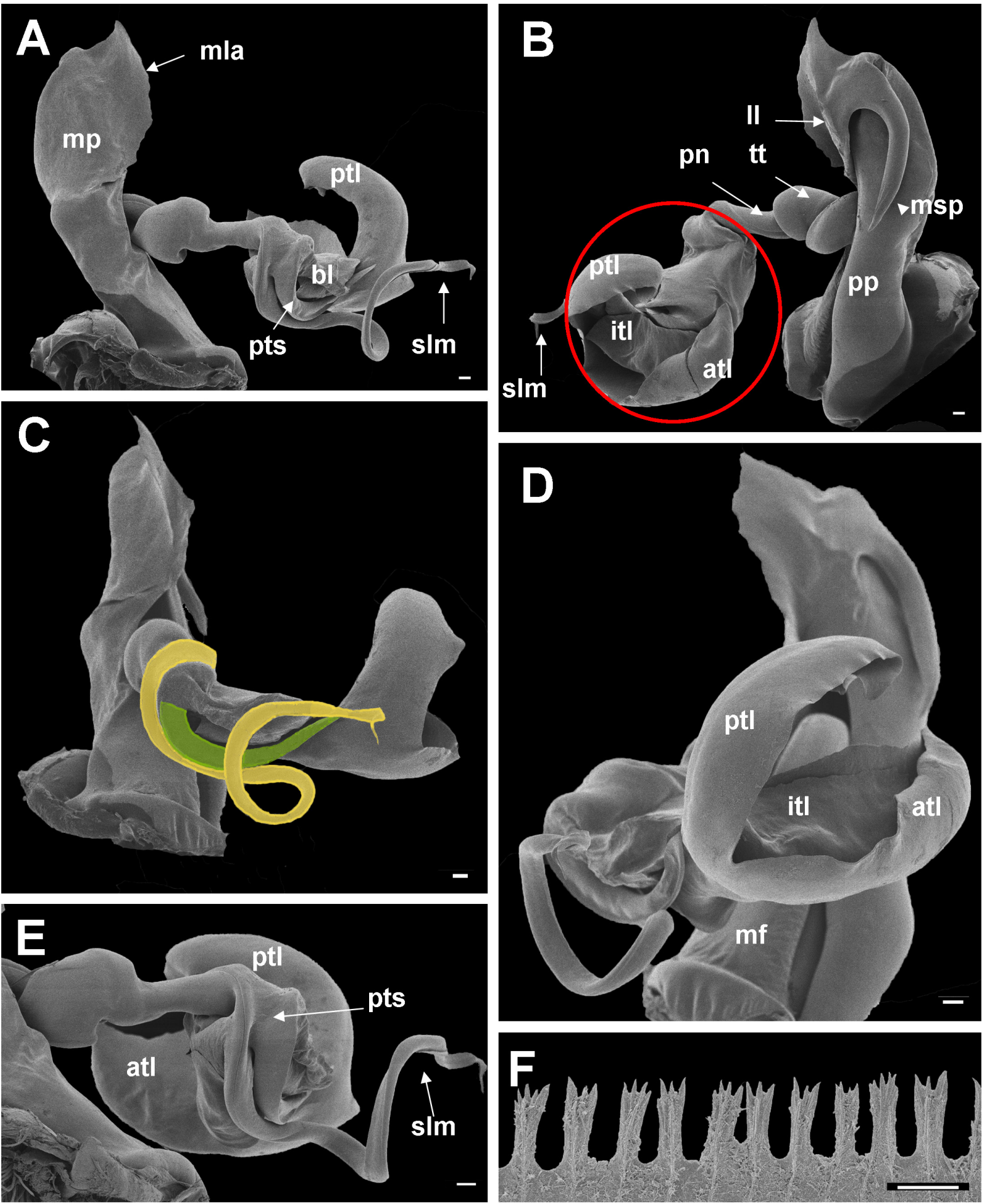

Fig 4. Geotypodon millemanus gen. et sp. nov., paratype from Kiranzi-Kitungulu FR. A-E: Right gonopod. A. Posterior view. B. Anterior view, telomere in red oval. C. (Posterior-)mesal view, solenomere (yellow) and proximal telomeral spine (green) coloured. D. (Anterior-)mesal view. E. Telomere (part of coxa at lower left), basal (dorsal) view. F. Limbus. Abbreviations: atl = anterior distal lobe of telomere; $b l=$ basal lamella of telomere; $i t l=$ intermediate distal lamella of telomere; $l l=$ longitudinal lamella; $m f=$ anteriad metaplical flange; $m l a=$ metaplical lamella; $m p=$ metaplica; $m s p=$ metaplical spine-like process $; n=$ posttorsal narrowing; $p p=$ proplica; $p t l=$ posterior distal lobe of telomere; $p t s=$ proximal telomeral spine; $s l m=$ solenomere; $t t=$ torsotope. Scales: $\mathrm{A}-\mathrm{E}=0.1 \mathrm{~mm}, \mathrm{~F}=0.01 \mathrm{~mm}$. 
ENGHOFF H., New millipede genus and species from the Udzungwa Mts

\section{Type locality}

TANZANIA, Iringa Region, Iringa District, Udzungwa Mts, West Kilombero Scarp FR, 0750'38.4" S, $36^{\circ} 22^{\prime} 17.6^{\prime \prime}$ E, montane forest, 1390-1410 m asl, cf. Marshall et al. (2001).

\section{Description}

SizE. Length ca. $9 \mathrm{~cm}$. Diameter $4.8-5.1 \mathrm{~mm}$. 60-66 podous rings, no apodous rings in front of telson.

CoLour. After 15 years in alcohol somewhat faded, but pattern still evident. Upper part of head blackish, lower part yellowish. Overall colour of body ventrally and laterally yellowish. Posterior ca. $40 \%$ of metazona amber, in front of amber zone a blackish zone; blackish zone narrow laterally, becoming wider dorsally where extending onto posterior $1 / 4-1 / 3$ of prozona; resulting mid-dorsal dark band becoming narrower towards head. Telson blackish with yellowish margins, legs yellowish.

HeAD. Without peculiarities.

ColLum. With a marginal and a submarginal furrow.

BoDy RINGs. Almost perfect cylinders, not vaulted; suture straight; ozopores ca. three diameters behind suture.

LimBus (Fig. 4). Consisting of isolated hand-like lobes of ca. 10 microns' length, each with 3-6 'fingers' and each with a ridge running along its length.

ANAL VALVES. Each with a well-developed dorsal spine and a smaller, yet distinctive ventral one; margin raised, with 3 setae not borne on tubercles.

MaLe LeGs. From $5^{\text {th }}$ pair with postfemoral and tibial pads on all legs, except last four pairs; tibial pads absent from several pairs in front of these.

GoNOPOD COXA (Fig. 4). Slender, slightly sigmoid. Proplica ( $p p$ ) ending in small proplical lobe hidden behind anterior edge of metaplical lamella $(m l a)$, on Fig. 4B. Metaplica $(m p)$ with poorly developed basal anteriad flange $(\mathrm{mf})$, disto-mesally expanded into thin lamella $(\mathrm{mla})$, with a straight mesal margin, tip of metaplica formed by blunt-triangular extension of mla; a second smaller longitudinal lamella $(l l)$ on anterior surface of metaplica partly covering proplical lobe; metaplica at level of proplical lobe, with a long, slightly curved spine-like process ( $m s p$ ) directed toward base of coxa on its anterior side.

Gonopod telopodite (Fig. 4). Arculus $90^{\circ}$. Torsotope ( $t t$ ) simple, compact, without processes (Fig. 4B). Posttorsal narrowing $(p n)$ pronounced, very slender, without processes or spines (Fig. 4B). Telopodite just distal to posttorsal narrowing dividing into slender, whip-like solenomere and complicated telomere. Solenomere $(\mathrm{s} / \mathrm{m})$ curved in 3 dimensions (at least on preserved specimens), apically pointed, without any outgrowths (Fig. 4A, C, E). Efferent groove continuing from posttorsal narrowing onto solenomere and running all the way to its tip. Telomere with long, stout basal spine ( $p t s)$, spine first curving in parallel with solenomere, but then becoming straight and directed mesad (Fig. 4A, C). Telomere close to $p t s$ with a basal lamella ( $b l$ ) (Fig. 4A), followed by several complicated lamellar parts; basal part of telomere partly sheathing base of solenomere, distal part divided into two equally-sized thin lobes ( $a t l$ and $p t l$ ), which initially diverge at ca. $90^{\circ}$ but then curve towards each other (Fig. 4B, D-E). An intermediate lamella (itl) lodged in the space between atl and $p l m$ (Fig. 4D). Surfaces of atl and $p t l$ facing each other, concave, margins of each lobe subparallel, smooth; telomere entirely without denticles or spines. 


\section{Distribution and habitat}

Known from West Kilombero FR and Kiranza-Kitungulu FR. Altitudinal range: 1145-1500 m asl. Haibtat: (montane) forest.

\section{Coexisting species}

In Kiranza-Kitungulu FR G. millemanus gen. et sp. nov. was found in the same sample as Chaleponcus dabagaensis Kraus, 1958 and C. gracilior Enghoff, 2014. In West Kilombero FR no other odontopygids were found in the same sample as G. millemanus gen. et sp. nov., but G. submontanus gen. et sp. nov., Chaleponcus basiliscus Enghoff, 2014, C. circumvallatus Enghoff, 2014, C. gracilior, C. ibis Enghoff, 2014, C. netus Enghoff, 2014, C. tintin Enghoff, 2015, Aquattuor longipala Enghoff 2015 and A. udzungwensis Enghoff, 2015 also occur in West Kilombero FR.

Geotypodon submontanus gen. et sp. nov. urn:1sid:zoobank.org:act:02DBFF6A-56A1-4EB3-9001-AF063F22C1B6

Figs $1,3,5$

\section{Diagnosis}

A species of Geotypodon gen. nov. in which the gonopod coxal metaplica is produced mesad in a thin lamella, a small longitudinal lamella, perpendicular to the other, is present on the anterior part of the metaplica, the telomere is apically divided into two lobes of approximately equal size, and the limbus lobes are multi-cusped, hand-like. Shares these characters with G. millemanus gen. et sp. nov., but differs from that species in smaller size, bicuspid mesal margin of metaplical lamella and presence of a spine-like process on the posterior apical telomeral lobe.

\section{Etymology}

The name is a Latin adjective referring to the habitat.

Material studied (total: 1 ふ)

Holotype

TANZANIA: $\widehat{\jmath}$, Iringa Region, Iringa District, Udzungwa Mts, West Kilombero Scarp FR, 0753'19.5" S, 36²3'11.6" E, submontane forest, $1145 \mathrm{~m}$ asl, trapsite Ukami, casual, Nov. 2000, Frontier Tanzania leg. (ZMUC00046992).

\section{Type locality}

TANZANIA, Iringa Region, Iringa District, Udzungwa Mts, West Kilombero Scarp FR, 0753'19.5" S, 36²3'11.6" E, submontane forest, $1145 \mathrm{~m}$ asl, cf. Marshall et al. (2001).

\section{Description}

SizE. Length ca. $7 \mathrm{~cm}$. Diameter $3.8 \mathrm{~mm}$. 60 podous rings, no apodous rings in front of telson.

OTHER CHARACTERs. As in G. millemanus gen. et sp. nov., with the following exceptions:

- telson (after 15 years in alcohol) yellowish,

- postfemoral and tibial pads on male legs smaller,

- metaplical lamella ( $m l a)$ produced mesad, with two sharp angles (Fig. 5A-B),

- posterior distal lobe of telomere ( $p t l)$ apically with a dark, spine-like process (Fig. 5E).

\section{Distribution and habitat}

Known only from West Kilombero FR. Altitude: $1145 \mathrm{~m}$ asl. Habitat: submontane forest. 
ENGHOFF H., New millipede genus and species from the Udzungwa Mts
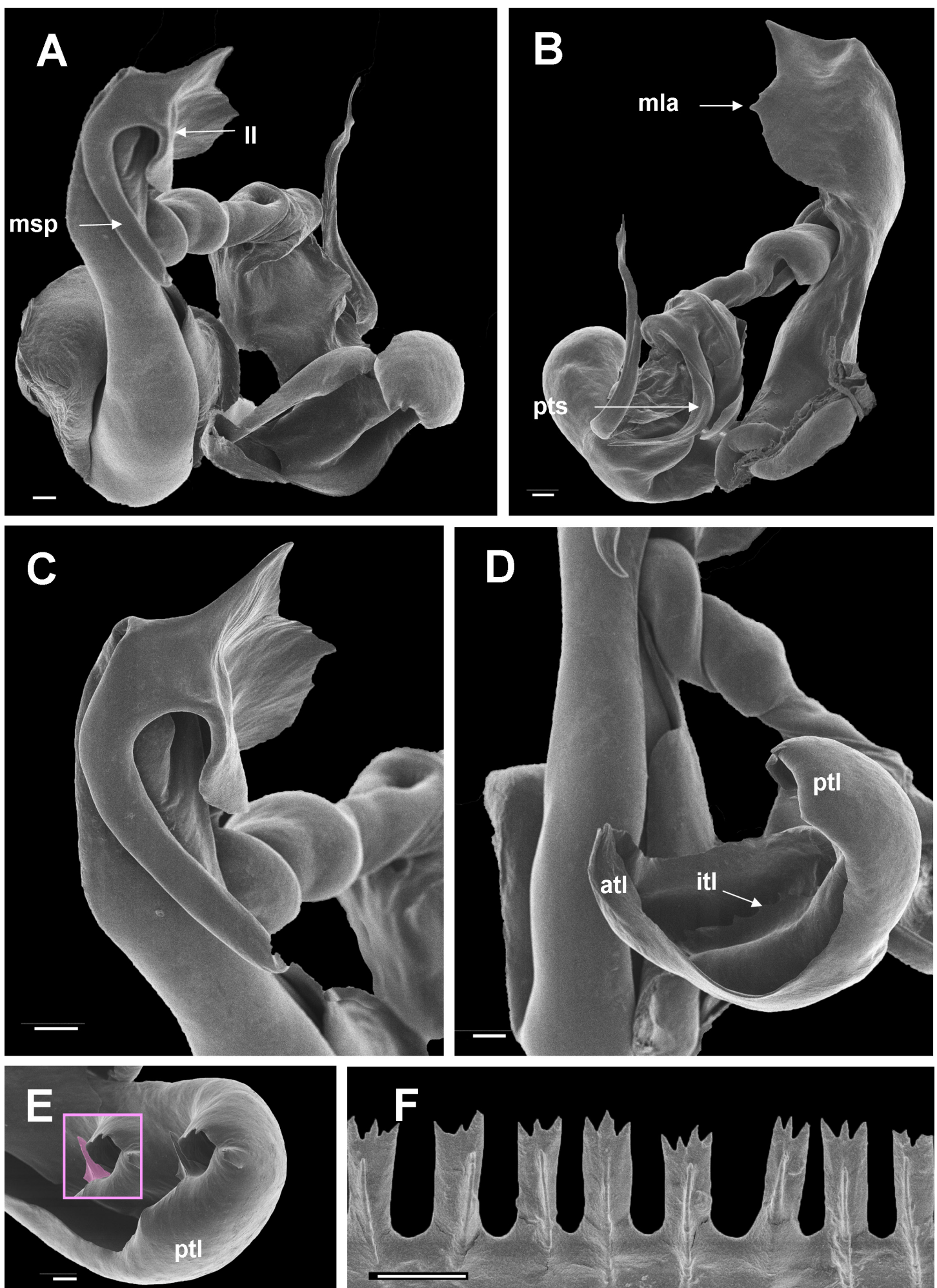

Fig. 5. Geotypodon submontanus gen. et sp. nov., holotype. A-E. Left gonopod. A. Anterior view. B. Posterior view. C. Apical part of coxa and proximal part of telopodite, anterior view. D. (Anterior-) mesal view. E. Posterior distal lobe of telomere; insertion highlights spine-like process. F. Limbus. Abbreviations: $a t l=$ anterior distal lobe of telomere; $i t l=$ intermediate distal lamella of telomere; $l l=$ longitudinal lamella; $m l a=$ metaplical lamella; $m s p=$ metaplical spine-like process; $p t l=$ posterior distal lobe of telomere; $p t s=$ proximal telomeral spine. Scales: $A-D=0.1 \mathrm{~mm}, \mathrm{E}=0.05 \mathrm{~mm}, \mathrm{~F}=0.01 \mathrm{~mm}$. 


\section{Coexisting species}

No other odontopygids were found in the same sample as G. submontanus gen. et sp. nov., but G. millimanus gen. et sp. nov., Chaleponcus basiliscus Enghoff, 2014, C. circumvallatus Enghoff, 2014, C. gracilior, C. ibis Enghoff, 2014, C. netus Enghoff, 2014, C. tintin Enghoff, 2015, Aquattuor longipala Enghoff, 2015 and A. udzungwensis Enghoff, 2015 also occur in West Kilombero FR.

Geotypodon iringensis gen. et sp. nov. urn:1sid:zoobank.org:act:0171D40F-1E0D-4194-8D1B-045D46F92095

Figs 1, 3, 6

\section{Diagnosis}

A species of Geotypodon gen. nov. in which the gonopod coxal metaplica is apically rounded, the telomere is apically divided into a small posterior lobe and a large anterior lobe, which gives rise to a strongly curved terminal lobe, and the limbus lobes are pointed triangular.

\section{Etymology}

The species is named after the type locality.

Material studied (total: $2 \hat{\jmath}$ )

Holotype

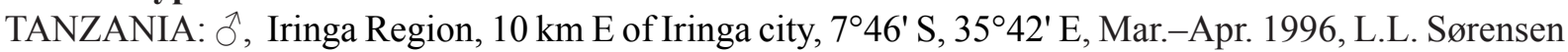
leg. (ZMUC00046993).

Paratype

TANZANIA: 1 ○, same data as holotype (ZMUC00046994).

\section{Type locality}

TANZANIA: Iringa Region, 10 km east of Iringa city, $7^{\circ} 46^{\prime} \mathrm{S}, 35^{\circ} 42^{\prime} \mathrm{E}$.

\section{Description}

SizE. Length ca. $9 \mathrm{~cm}$. Diameter 6.0-6.1 mm. 61-67 podous rings, no apodous rings in front of telson.

CoLour. After 19 years in alcohol uniform greyish; posterior part of metazona amber, legs and antennae dark brownish.

HEAD. Without peculiarities.

Collum. With a marginal and a submarginal furrow.

BoDy RINGS. Almost perfect cylinders, not vaulted; suture straight; ozopores $c a$. three diameters behind suture.

LimBus (Fig. 6). With sharply pointed lobes.

ANAL VALVES. Each with a well-developed dorsal spine and a smaller, yet distinctive ventral one, margin raised, with 3 setae not borne on tubercles.

Male Legs. From $4^{\text {th }}$ pair with postfemoral and tibial pads on all legs, except last few pairs where only postfemoral pads are present. 

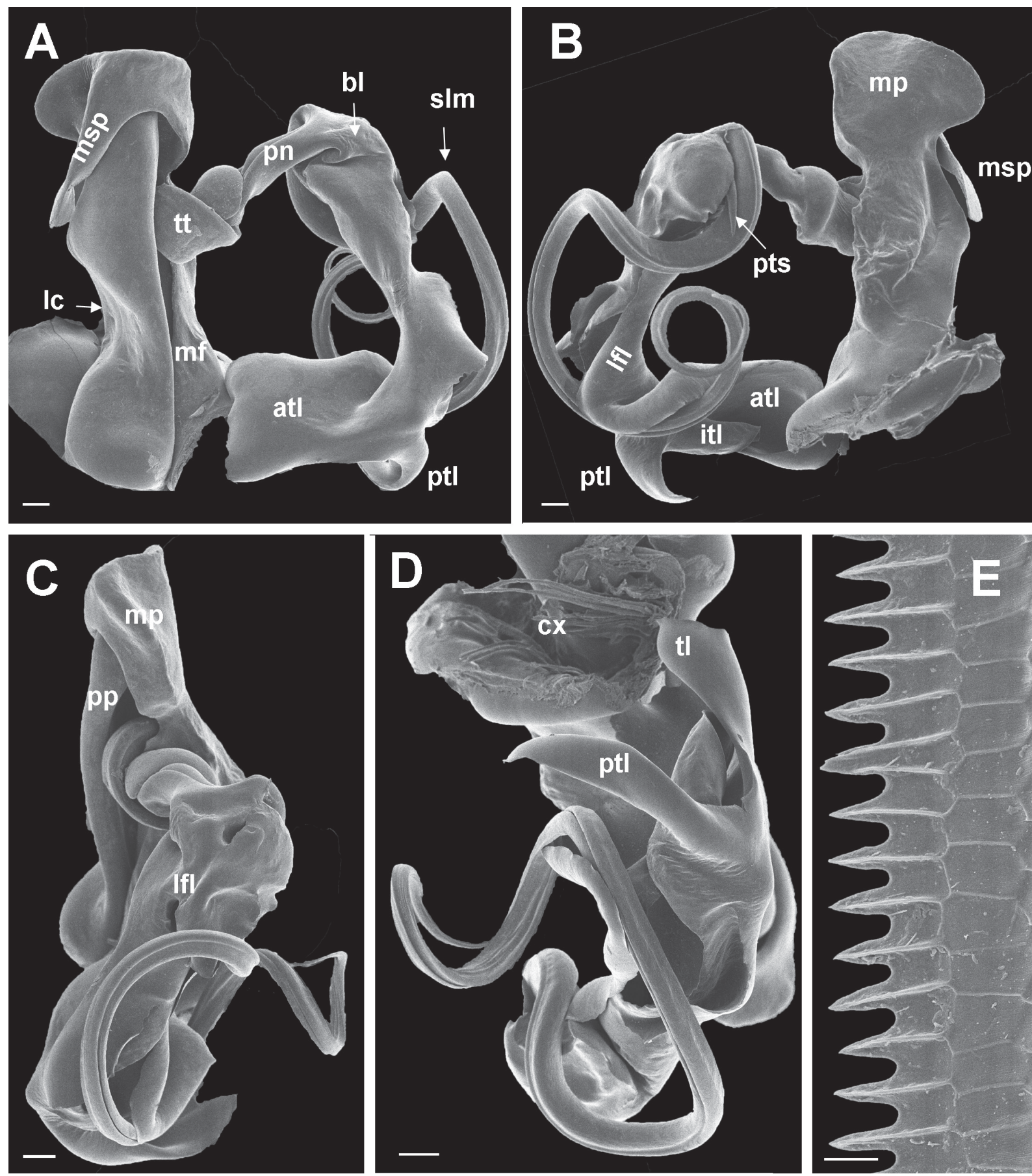

Fig. 6. Geotypodon iringensis gen. et sp. nov. A-D. Holotype, left gonopod. A. Anterior view. B. Posterior view. C. Mesal-ventral view. D. Telomere and solenomere, basal (dorsal) view. - E. Paratype, limbus. Abbreviations: $a t l=$ anterior distal lobe of telomere, $b l=$ basal lamella of telomere, $c x=$ coxa (seen from the basis, with remains of muscles); $i t l=$ intermediate distal lamella of telomere; $l c=$ lateral concavity of coxa; $l f l=$ longitudinally folded lamella; $m f=$ anteriad metaplical flange; $m p=$ metaplica; $m s p=$ metaplical spine-like process; $p n=$ posttorsal narrowing; $p p=$ proplica; $p t l=$ posterior distal lobe of telomere; $p t s=$ proximal telomeral spine; $s l m=$ solenomere; $t l=$ terminal lobe of telomere; $t t=$ torsotope. Scales: A-D $=0.2 \mathrm{~mm}, \mathrm{E}=0.01 \mathrm{~mm}$. 
GonOPOD COXA (Fig. 6). Basally parallel-sided, with antero-lateral concavity (lc) (Fig. 6A). Proplica ending in small proplical lobe (hidden behind anterior edge of metaplica on Fig. 6A). Metaplica with poorly developed basal anteriad flange ( $m f$ ) (Fig. 6A), distally regularly rounded and projecting laterad as semicircular lobe; metaplica at level of proplical lobe, with a long, latero-basad process ( $m s p$ ) on anterior side of coxa (Fig. 6A-B); process straight and slender in anterior view, slightly curved and broader in lateral view.

Gonopod telopodite (Fig. 6). Arculus $90^{\circ}$. Torsotope ( $t t$ ) simple, compact, without processes (Fig. 6A). Posttorsal narrowing $(p n)$ pronounced, very slender, without processes or spines (Fig. 6A). Telopodite just distal to posttorsal narrowing dividing into slender, whip-like solenomere and complicated telomere. Solenomere ( $\mathrm{slm}$ ) curved in 3 dimensions (at least on preserved specimens), apically pointed, without any outgrowths (Fig. 6A-D). Efferent groove continuing from posttorsal narrowing onto solenomere and running all the way to its tip. Telomere with short, dark basal spine (pts) (Fig. 6B) and a basal lamella (bl) (Fig. 6A), followed by a slender part formed by a longitudinally folded lamella $(l f l)$ with irregular edges (Fig. 6B-C); distal part divided into a slender posterior lobe $(p t l)$ and a large, broad anterior lobe (atl) (Fig. 6A-B, D), the latter terminally giving rise to a slender, strongly curved terminal lobe ( $t l$, curvature not visible on Fig. 6D). An intermediate lamella (itl) lodged in the space between atl and $p \operatorname{lm}$ (Fig. 6B).

\section{Distribution and habitat}

Known only from the environs of Iringa city. The altitude of the type locality will be at $c a .1600 \mathrm{~m}$ asl.

\section{Coexisting species}

No other odontopygid species were found together with G. iringensis gen. et sp. nov.

\section{Notes}

Geotypodon iringensis gen. et sp. nov. is very similar to G. multianulatus from Kenya, but there are differences, including that in G. multianulatus the gonopod coxa has a much larger, narrower and less rounded lateral lobe, and the solenomere has a small subdistal spine (cf. Discussion section).

\section{Discussion}

Of the three species described here, G. millemanus gen. et sp. nov. and G. submontanus gen. et sp. nov., both from the Udzungwa Mountains proper, are particularly similar, notably sharing the lamellar structure of the mesal part of the coxal metaplica and the apically divided telomere with an intermediate lamella (itl) between the apical and posterior distal lobes ( $a t l$ and $p t l)$. G. iringensis gen. et sp. nov. does not have the metaplical lamella, but its telomere has the same distal elements ( $a t l, i t l, p t l)$ as the two other species. In most other species of Geotypodon gen. nov. as here defined, the telomere does not show a similar apical subdivision. Exceptions are G. multianulatus, G. sennae and G. specularis, where the telomere is divided into two large lobes (Attems 1914, 1927; Brölemann 1903).

The unsatisfactory state of odontopygid taxonomy was characterized as follows by Hoffman \& Howell (2012): "That classification of odontopygid millipeds remains in a highly unsettled condition is due both to the inherent complexity of the male genitalia and the traditional reliance on a few obvious key-characters (a priori definition) instead of groupings made on the basis of overall similarity of the appendages. Either approach is further complicated by frequent contradictory states of characters as expressed in coxal or telopodital regions. Almost identical coxal forms may recur randomly amongst taxa defined on the basis of the telopodite and thought to be not closely related. Body form tends to be of monotonous similarity throughout the group, and female genitalia have so far provided very few insights into relationships." Hoffman \& Howell went on to speculate that "The impression is thus gained 
of a group of organisms which have stabilized their general Gestalt whilst expressing innate genetic variability dominantly in permutations of male reproductive structures. A young evolutionary status is implied by the paucity of strong discontinuities in character systems and typical spectral expression of traits." Anybody who has tried to refer odontopygid specimens to a genus will agree that this is not easy. Whereas the gonopods of each species are often highly characteristic, when it comes to grouping the species, the problems are massive.

As an illustrative example, one may mention the record of Odontopyge cf. picea by Dieudonné (2014). The record is illustrated with a very nice optical photo of the gonopods, and they do indeed look very much like Geotypodon picea gen. et comb. nov. Examination of several specimens from among the material recorded by Dieudonné, kindly put at my disposal by Didier VandenSpiegel (Royal Museum for Central Africa, Tervuren, Belgium), did, however, reveal that whereas the specimens in most respects agree with the definition of Geotypodon gen. nov. given above, they differ in a striking detail: just distal to the posttorsal narrowing where the solenomere and the telomere begin, there is a peculiar sclerite protruding from the main telopodite axis. The basal telomeral spine sometimes curves between this sclerite and the main axis. Such a sclerite is absent from the true G. picea (Attems 1938: fig. 32). Furthermore, the solenomere of these specimens has a tiny spine-like side branch near the tip, whereas the solenomere tip is not visible on Attems' figure and is not mentioned in the description. (As noted above, one of the few differences between G. iringensis gen. et sp. nov. and G. multianulatus is that the latter species has a similar small subapical spine.)

An alternative approach to odontopygid classification is clearly needed, and molecular characters are the obvious choice. This will, however, require a huge effort. A search for "Odontopygidae" in GenBank yields no results whatsoever, so there is scope for large-scale sampling and sequencing of well-vouchered odontopygids.

This way, a more satisfactory classification may one day be obtained, but until then, in order to be able to handle the amazing diversity of odontopygids, several existing genera need to be revised and probably split into several smaller genera. This approach might seem to be at variance with the ideas expressed by Hoffman \& Howell (2012), i.e., "traditional reliance on a few obvious key-characters (a priori definition) instead of groupings made on the basis of overall similarity", but at least as a temporary solution such a splitting approach will be useful. Taking the monographic work of Kraus $(1960,1966)$ as the starting point, several such splits have already been made by Demange (1981), Frederiksen \& Enghoff (2015), Hoffman (2002) and Hoffman \& Howell (2012). One further split is proposed in the present paper.

Around 400 species of Odontopygidae have been described (Enghoff 2014), but virtually every new collection of millipedes from the Afrotropical region contains undescribed species. The number of described odontopygid species can therefore potentially be multiplied by an unknown factor (5? 10?), and the number of genera will - at least temporarily - also need to be multiplied, hopefully to a somewhat smaller degree.

\section{Acknowledgements}

Thanks are due to Mogens Andersen, Peter Gravlund, Andy Jakobsen and Line Sørensen, as well as Frontier Tanzania, for collecting the specimens studied here, to Hans Reip for providing access to old literature, to Nicholas Ioannou for photography, and to Didier VandenSpiegel, Royal Museum for Central Africa, Tervuren, Belgium, for lending important comparative material. 


\section{References}

Attems C. 1909. Myriopoda. Wissenschaftliche Ergebnisse der schwedischen zoologischen Expedition nach dem Kilimandjaro, dem Meru und den umgebenden Massaisteppen Deutsch-Ostafrikas 1905-1906 3 (19): 1-64.

Attems C. 1912. Myriopoden. Wissenschaftliche Ergebnisse der deutschen Zentral-Afrika-Expedition 1907-1908 unter Führung Adolf Friedrichs, Herzog zu Mecklenburg 4 (Zoologie): 297-324.

Attems C. 1914. Afrikanische Spirostreptiden nebst Überblick über die Spirostreptiden orbis terrarum. Zoologica 25 (65/66): 1-233.

Attems C. 1927. Diplopoda. Wissenschaftliche Ergebnisse der Expedition R. Grauer nach Zentralafrika, Dezember 1909 bis Februar 1911. Annalen des naturhistorischen Museums Wien 41: 51-90.

Attems C. 1938. Diplopoden des Belgischen Congo. Polydesmoidea, 2. Nachtrag und Spirostreptoidea, 1. Nachtrag. Revue de Zoologie et de Botanique Africaines 31: 225-313.

Attems C. 1953. Neue Myriapoden des Belgischen Congo. Annales du Musée Royal du Congo Belge, Sciences zoologiques 18: i-xii + 1-139.

Brölemann H.W. 1903. Materiali per lo studio della Fauna Eritrea raccolti nel 1901-03 dal dr. A. Andreini tenente medico. I. Myriapodes. Bollettino della Società entomologica italiana 35: 96-153. http://biodiversitylibrary.org/page/25171941

Demange J.-M. 1981. Contribution à la connaissance de la faune myriapodologique du Zaïre (Myriapoda: Diplopoda). Pubblicazioni dell'Istituto di Entomologia dell'Università di Pavia 15: 1-19.

Demange J.-M. 1990. Sur une collection de Myriapodes de l'Ouganda (massif de Ruwenzori). (Diplopodes et Chilopodes). Atti della Accademia nazionale dei Lincei. Rendiconti Classe di scienze fisiche, matematiche e naturali. Sezione III (Botanica, zoologia, fisiologia e patologia) 87: 553-560.

Doody K.Z., Howell K.M. \& Fanning E. (eds) 2001. West Kilombero Scarp Forest Reserve - Zoological Report. Report for the Udzungwa Mountains Forest Management and Biodiversity Conservation Project, MEMA, Iringa, Tanzania.

Enghoff H. 2014. A mountain of millipedes I: An endemic species-group of the genus Chaleponcus Attems, 1914, from the Udzungwa Mountains, Tanzania (Diplopoda, Spirostreptida, Odontopygidae). European Journal of Taxonomy 100: 1-75. http://dx.doi.org/10.5852/ejt.2014.100

Enghoff H. \& Frederiksen S.B. 2015. A mountain of millipedes II: The genus Aquattuor Frederiksen, 2013 - five new species from the Udzungwa Mountains and one from Mt. Kilimanjaro, Tanzania (Diplopoda, Spirostreptida, Odontopygidae). European Journal of Taxonomy 150: 1-25. http://dx.doi. org/10.5852/ejt.2015.150

Frederiksen S.B. \& Enghoff H. 2015. East African odontopygid millipedes 4: A restricted redefinition of the genus Rhamphidarpoides Kraus, 1960, a related new genus, five new species, and notes on solenomere function (Diplopoda; Spirostreptida; Odontopygidae). Zootaxa 3926: 541-560. http:// dx.doi.org/10.11646/zootaxa.3926.4.5

Hoffman R.L. 1980 (for 1979). Classification of the Diplopoda. Muséum d'Histoire naturelle, Geneva.

Hoffman R.L. 1991. What is Odontopyge? A solution to a long standing nomenclatorial enigma in the Diplopoda (Spirostreptida Odontopygidae). Tropical Zoology 4: 65-73. http://dx.doi.org/10.1080/0394 6975.1991.10539475

Hoffman R.L. 2000. A note on the identity of Spirostreptus acutus Karsch (Spirostreptida, Odontopygidae). Myriapodologica 7 (4): 29-33.

Hoffman R.L. 2002. Review of Callistodontopyge, a genus of strikingly colored East African diplopods (Spirostreptida: Odontopygidae). Myriapodologica 7 (10): 85-99. 
ENGHOFF H., New millipede genus and species from the Udzungwa Mts

Hoffman R.L. \& Howell K.M. 1981. A new genus, composed of brightly colored East African species, in the diplopod family Odontopygidae (Myriapoda, Diplopoda). Revue de Zoologie africaine 95 (3): 687-696.

Hoffman R.L. \& Howell K.M. 2012. A new genus of odontopygid millipedes from Tanzania (Diplopoda: Spirostreptida: Odontopygidae). Journal of East African Natural History 101 (1): 67-72. http://dx.doi. org/10.2982/028.101.0104

Jeekel C.A.W. 1970. Nomenclator Generum et Familiarum Diplopodorum. A List of the Genus and Family-Group Names in the Class Diplopoda from the $10^{\text {th }}$ Edition of Linnaeus, 1758, to the end of 1957. Monografieën van de Nederlandse Entomologische Vereniging 5, Leiden, The Netherlands.

Kraus O. 1958. Myriapoda (Chilopoda, Diplopoda). Parc National de l'Upemba I. Mission G.F. de Witte 54 (1): 1-67.

Kraus O. 1960. Äthiopische Diplopoden I. Monographie der Odontopygidae-Odontopyginae (Diplopoda, Spirostreptoidea). Annalen van het Koninklijk Museum van Belgisch-Congo 82: 1-207.

Kraus O. 1966. Phylogenie, Chorologie und Systematik der Odontopygoideen (Diplopoda, Spirostreptomorpha). Abhandlungen der Senckenbergischen Naturforschenden Gesellschaft 512: 1-143.

Marshall A.R., Brink H. \& Topp-Jørgensen J.E. 2001. Millipede Diversity and Distribution - West Kilombero Scarp Forest Reserve. In: Doody K.Z., Howell K.M., \& Fanning E. (eds) West Kilombero Scarp Forest Reserve - Zoological Report: 124-132. Report for the Udzungwa Mountains Forest Management and Biodiversity Conservation Project, MEMA, Iringa, Tanzania.

Marshall A.R., Jørgensbye H.I.O., Rovero F., Platts P.L., White P.C.L. \& Lovett J.C. 2010. The speciesarea relationship and confounding variables in a threatened monkey community. American Journal of Primatology 72: 325-336. http://dx.doi.org/10.1002/ajp.20787

Ntashavu D. 2014. Etude systématique et écologique des Diplopodes des écosystèmes forestiers du Burundi occidental. Rapport de stage au Musée Royal de l'Afrique Centrale de Tervuren, Belgique. Available from http://bi.chm-cbd.net/biodiversity/documents-sur-la-biodiversite-du-burundi/recherches-en-cours/ recherches-pour-2014/recherche-sur-les-araignees-des-ecosystemes-forestiers-du-burundi/etudesystematique-et-ecologique-des-diplopodes-des-ecosystemes-forestiers-du [accessed on 19 Feb. 2016]

Pierrard G. 1970. Odontopygidae nouveaux d'Afrique centrale (Myriapoda - Diplopoda). Revue de Zoologie et de Botanique africaines 81 (1-2): 197-206.

Silvestri F. 1896. I Diplopodi. Parte 1. Sistematica. Annali del Museo civico di Storia Natural di Genova 36: 121-254. http://biodiversitylibrary.org/page/7697911

Manuscript received: 8 October 2015

Manuscript accepted: 26 November 2015

Published on: 26 February 2016

Topic editor: Rudy Jocqué

Desk editor: Kristiaan Hoedemakers

Printed versions of all papers are also deposited in the libraries of the institutes that are members of the EJT consortium: Muséum national d'Histoire naturelle, Paris, France; Botanic Garden Meise, Belgium; Royal Museum for Central Africa, Tervuren, Belgium; Natural History Museum, London, United Kingdom; Royal Belgian Institute of Natural Sciences, Brussels, Belgium; Natural History Museum of Denmark, Copenhagen, Denmark. 